\title{
Tumor Cell Dissemination and Metastasis in Breast Cancer: Selected Presentations at the 28th San Antonio Breast Cancer Symposium 2005
}

\author{
Volkmar Müller ${ }^{a^{*}} \quad$ Elmar Stickeler ${ }^{b^{*}}$ \\ a Universitätsklinikum Hamburg-Eppendorf,

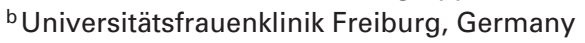

Key Words

Breast cancer - Tumor cells, disseminated - Tumor cells, circulating · Tumor cell homing · Organ tropism

\section{Summary}

Distant metastases are the leading cause of breast cancer-related deaths. Early tumor cell dissemination as the first step in the metastatic cascade can be detected in breast cancer patients using sensitive assays. Clinical studies demonstrated that the presence of disseminated tumor cells in bone marrow identified with immunocytochemical assays at primary diagnosis is a strong prognostic factor indicating a biologic relevance of these cells. However, the molecular basis enabling malignant cells to grow out as manifest metastasis are still not fully understood. In this context, considerable progress has been made by analyzing distinct gene function in the metastatic cascade as well as in establishing gene expression signatures which are able to classify the risk of developing organ-specific metastases. Here, we briefly describe and discuss new aspects of these topics presented at the 28th San Antonio Breast Cancer Symposium 2005.

\author{
Schlüsselwörter \\ Mammakarzinom - Tumorzellen, disseminierte . \\ Tumorzellen, zirkulierende · Tumorzell-Homing · \\ Organtropismus
}

\section{Zusammenfassung}

Fernmetastasen sind die Haupttodesursache bei Patientinnen mit einem Mammakarzinom. Eine frühe Tumorzelldissemination als erster Schritt in der Metastasierungskaskade kann mit Hilfe sensitiver Nachweisverfahren erfasst werden. Klinische Studien haben gezeigt, dass der immunzytochemische Nachweis disseminerter Tumorzellen im Knochenmark ein starker Prognosefaktor bei Patientinnen mit primärem Mammakarzinom ist. Dies ist ein Beleg für die biologische Relevanz solcher Zellen. Die molekularen Mechanismen, die es Zellen ermöglichen, klinisch manifeste Makrometastasen zu bilden, sind noch in vielen Bereichen ungeklärt. In diesem Zusammenhang zeigen sich erhebliche Fortschritte durch die Analyse der Funktion einzelner Gene im Rahmen der Metastasierungskaskade und die Etablierung von Genexpressionssignaturen, die eine Risikoabschätzung für das Entstehen organspezifischer Metastasen ermöglichen. In dem folgenden Artikel sollen neue Aspekte dieser Themengebiete vorgestellt werden, die auf dem 28. San Antonio Breast Cancer Symposium 2005 präsentiert wurden.

\footnotetext{
*As members of the Working Group on Translational Research, part of the AGO (Working Group Gynecologic Oncology, German Society of Obstetrics and Gynecology)
}

\begin{tabular}{ll}
\hline KARGER & ( ) 2006 S. Karger GmbH, Freiburg \\
Fax +49 76145207 14 & Accessible online at: \\
$\begin{array}{l}\text { E-mail Information@Karger.de } \\
\text { www.karger.com }\end{array}$ & www.karger.com/brc
\end{tabular}

Dr. med. Volkmar Müller 


\section{Introduction}

Immunocytochemical and molecular assays now enable the specific detection of disseminated tumor cells (DTC) in the blood and bone marrow (BM) as one of the first crucial steps in the metastatic cascade. However, not all patients with DTC in the BM or blood develop manifest metastasis. Therefore, deeper insight into the biology underlying the development of metastatic disease is needed. Tumor cell intravasation, survival in circulation, extravasation into distant organ sites, neo-angiogenesis and progressive tumor growth represent the pertinent steps of the metastatic process. So far, the molecular requirements underlying the tissue tropism of tumor cells are not yet fully understood. The functional analysis of distinct genes in the metastatic cascade as well as the validation of gene signatures in this context are important tools in the elucidation of this detrimental step of breast cancer progression. In this review, we will describe important findings presented at the 28th San Antonio Breast Cancer Symposium held in December 2005.

\section{Detection of Disseminated Tumor Cells in the Bone Marrow}

Currently, most experience with BM screening for occult metastatic breast cancer cells exists for immunocytochemical analyses using Ficoll density gradient centrifugation for tumor cell enrichment. The most recent studies reported that the presence of DTC in BM has a strong prognostic impact on patient survival. This was confirmed in a pooled analysis of Braun et al. [1,2] including 4,703 patients with a 10-year follow-up that was presented in a general session. These results provide conclusive level I evidence that the presence of DTC in $\mathrm{BM}$ is a significant indicator of poor prognosis in breast cancer patients. However, even in the studies included in the pooled analysis, different antibodies were used for the identification of DTC. Therefore, implementation of standards is of importance.

Another important application of DTC detection is the monitoring of therapeutic efficacy in the adjuvant setting. Several studies found DTC in BM even several years after surgery and adjuvant therapy and it seems that the presence of DTC after adjuvant treatment might be able to identify patients with an increased risk of recurrence [3-5]. In this context, Janni et al. [6] presented a pooled analysis of the European Working Group on DTC in BM. They analyzed BM aspirates of 584 patients during recurrence-free intervals. Relapse-free survival was longer in patients with negative BM status than in patients with positive BM status (159 vs. 91.5 months). Patients without persistent DTC had a significantly longer overall survival (165.5 months), than patients with positive BM status (104.0 months). In multivariate analysis, the presence of DTC in BM was an independent predictor for reduced breast cancer-specif- ic survival (relative risk 5.1). These findings demonstrate that persistence of DTC in BM indicates an increased risk of relapse and could be used for treatment monitoring in future clinical trials. Such trials might investigate the benefit of secondary adjuvant treatment and are of high clinical importance.

\section{Circulating Tumor Cells in the Peripheral Blood}

Peripheral blood would be an ideal source for the detection of DTC because of an easy sampling procedure. However, the prognostic significance of circulating tumor cells (CTC) is less clear than that of DTC in BM. The frequency of CTC in the blood seems to be lower, hence Ficoll gradient centrifugation may not provide sufficient enrichment of malignant cells. An important progress is the development a new automated enrichment and immunocytochemical detection system for CTC (CellSearch, Veridex, Warren, NJ, USA). Using this system, Cristofanilli et al. [7, 8] showed in a prospective study that CTC detection provided significant prognostic information both before and shortly after (4 weeks) initiation of chemotherapy in patients with metastatic breast cancer. However, clinical implications, optimal cut-off values for different patient groups and the possible relevance in patients with nonmetastatic breast cancer are not completely clear. The group showed that prognostic information from CTC determination can also be obtained in patients treated with endocrine therapy, but that the optimal time point for CTC evaluation in these patients may be later in the treatment than in patients treated with chemotherapy. In addition, for certain patient groups (e.g. patients with estrogen receptor-negative tumors) the clinical relevant number of CTC might be lower than 5 cells [9]. A prospective study is planned to evaluate whether patients with metastatic breast cancer and increased CTC numbers can profit from an early change of therapy. Also, 2 posters using the CellSearch system demonstrated that cells can be detected in BM and blood of patients with primary breast cancer $[10,11]$. Moreover, it seems to be possible to perform gene expression profiling from CTC enriched with this system [12] as well as with a different enrichment system based on immunomagnetic separation [13].

Several studies used polymerase chain reaction (PCR) techniques for the detection of DTC and demonstrated promising results. The major limiting factor for the detection of single tumor cells by RT-PCR (reverse transcription PCR) is the illegitimate low-level transcription of tumor-associated or epithelial-specific genes in normal cells $[14,15]$. Quantitative realtime RT-PCR provides interesting prospects for a better cutoff between mRNA expression in normal cells and tumor cells, thereby increasing the specificity of the RT-PCR approach. Harris et al. [16] showed that detection of CTC by PCR for cytokeratin 19 before neoadjuvant chemotherapy seems to be associated with an increased risk of recurrence. Kataoka et al. [17] examined the blood and BM of 246 pa- 
tients with primary breast cancer for the presence of tumor cells with a quantitative RT-PCR assay for cytokeratin 7 mRNA. In 186 patients available for follow-up, the presence of CTC in the blood, but not DTC in the BM was correlated with an impaired distant metastasis-free survival. In multivariate analysis, the presence of DTC in the blood was an independent prognostic factor in lymph node-negative patients. However, the results obtained with PCR methods must be validated in prospective multicenter studies. Nevertheless, findings presented at the Breast Cancer Symposium enhance the evidence that CTC detection has clinical relevance.

\section{Specific Homing-in on Breast Cancer Metastasis}

The multistep nature of breast cancer metastasis is an inefficient process whereby the majority of tumor cells are unable to develop at distant organ sites [18-20]. Only a rare number of cells will acquire this ability which was speculated to be related to the existence of distinct metastasis-mediating genes [21]. The establishment of DNA microarray technology has provided new insight into the genetic background of metastasis and has already identified gene signatures for breast cancer metastasis [22, 23]. However, the molecular basis of the diverse metastatic behavior of breast cancer, including the tissue tropism for lung, bone or liver, has not yet been characterized. Massague et al. [24-26] presented intriguing evidence for the existence of specific gene sets promoting lung metastasis when expressed in primary breast cancers. By means of in vivo selection in mice, aided by bioluminescence technology, the authors isolated breast cancer cells that were highly metastatic to the lung. Using microarray technology analysis, they identified gene sets whose expression was closely correlated with such organ-specific metastatic activity. A final list of 54 candidate genes was defined for the so-called lung metastagenicity and tumor virulence. These genes include those encoding epidermal growth factor member epiregulin (EREG), chemokine GRO1/CXCL1, MMP1, MMP2, the cell adhesion molecule SPARC, interleukin-13 decoy receptor IL13R $\alpha 2$, VCAM1 and the transcriptional inhibitor ID1, which were further elucidated in functional analyses. Clustering analysis from a cohort of 82 breast cancer patients found a subset of these metastasis genes frequently expressed in primary tumors with a high risk of relapsing to the lung, including MMP1, CXCL1, ID1, VCAM1 and EREG. The signature was shown to predict the specific risk of lung metastasis better than other markers, including the Rosetta-type poor prognosis signature [23] with a 10-year lung metastasis-free survival of 56 vs. $89 \%$ ( $\mathrm{p}=$ $0.0018)$. More interestingly, these genes were not general mediators of neoplastic growth but growth promotors within the breast and lung. The authors identified another subset of genes (including MMP2) which were overexpressed in rare virulently metastatic cells but only sporadically expressed in human tumors. These so-called virulence genes are postulated to enhance aggressive invasion, colonization and growth in the lung without promoting primary tumor growth. The hypothesis of specific gene involvement in tissue tropism of cancer cells is also supported by recent findings of specifically elevated MMP2 concentrations in pleural effusions of primary breast cancers [27]. Microarray-based technology was also applied by Moulder et al. [29] who in accordance to Massague et al. found genetic differences between primary tumors and lymph node metastases. Despite lacking functional analysis, these data support the involvement of distinct genes, especially extracellular proteins, and their expression patterns in tumor cell homing [28]. Further evidence in this regard is given by Cabioglu et al. [29]. Matched pairs of primary and metastatic breast cancers were analyzed, with the metastatic sites including bone, brain, lung and liver/omentum. CD44 was exclusively expressed in visceral but not in bone metastases. These results indicated that differential CD44 expression is a potential regulator of the homing of breast cancer cells to visceral organs.

The presented abstracts contribute significantly to the growing body of evidence for distinct gene expression correlated to the tropism of organ metastasis in breast cancer. Furthermore, these data are supported by functional in vivo and in vitro analysis of distinct candidate genes differentially expressed in the molecular signatures of metastasizing breast carcinomas. In conclusion, research with focus on tumor cell dissemination and homing is leading to an increased understanding of the metastatic cascade. Certain gene signatures will help to characterize the risk for breast cancer recurrences including potential organ sites where metastasis may occur. These predictive tools as well as the characterization of distinct gene functions might facilitate the development of new therapeutic approaches suppressing the development of metastatic disease. Novel findings of this research topic were presented at the San Antonio Breast Cancer Symposium 2005 and will in our opinion help to improve treatment of breast cancer patients.

\section{References}

1 Vogl FD, Braun S, Naume B, Janni W, Osborne M, Coombes RC, Schlimok G, Diel I, Gerber B, Gebauer G, Pierga JY, Marth C, Oruzio D, Wiedswang G, Solomayer E, Kundt G, Strobl B, Fehm T, Wong GY, Bliss J, Vincent-Salomon A, Pantel K: International pooled analysis of prognostic significance of bone marrow micrometastasis in patients with stage I, II, or III breast cancer. N Engl J Med 2005;353:793-802.
2 Braun S, Vogl FD, Pantel K: Collaborative Group Bone Marrow Micrometastasis: Meta- and pooled analysis of the prognostic value of bone marrow micrometastasis on disease outcome in 4,703 breast cancer patients: final results after 10 years of follow-up. Breast Cancer Res Treat 2005;94(suppl 1): abstr 5 .
3 Slade MJ, Singh A, Smith BM, Tripuraneni G, Hall E, Peckitt C, Fox S, Graham H, Luchtenborg M, Sinnett HD, Cross NC, Coombes RC: Persistence of bone marrow micrometastases in patients receiving adjuvant therapy for breast cancer: results at 4 years. Int J Cancer 2005;114:94-100. 
4 Janni W, Rack B, Schindlbeck C, Strobl B, Rjosk D, Braun S, Sommer H, Pantel K, Gerber B, Friese K: The persistence of isolated tumor cells in bone marrow from patients with breast carcinoma predicts an increased risk for recurrence. Cancer 2005;103: 884-91.

5 Wiedswang G, Borgen E, Karesen R, Qvist H, Janbu J, Kvalheim G, Nesland JM, Naume B: Isolated tumor cells in bone marrow three years after diagnosis in disease-free breast cancer patients predict unfavorable clinical outcome. Clin Cancer Res 2004;10:5342-8.

6 Janni W, Wiedswang G, Borgen E, Braun S, Rack B, Schindlbeck C, Sommer H, Pantel K, Heinrigs M, Nesland J, Scholz C, Friese K, Jeschke U, Naume B: Persistence of isolated tumor cells (ITC) in bone marrow $(\mathrm{BM})$ of breast cancer patients predicts increased risk for relapse - results of pooled European data. Breast Cancer Res Treat 2005;94(suppl 1):abstr 1016.

7 Cristofanilli M, Budd GT, Ellis MJ, Stopeck A, Matera J, Miller MC, Reuben JM, Doyle GV, Allard WJ, Terstappen LW, Hayes DF: Circulating tumor cells, disease progression, and survival in metastatic breast cancer. N Engl J Med 2004;351: 781-91.

$\checkmark$ Cristofanilli M, Hayes DF, Budd GT, Ellis MJ, Stopeck A, Reuben JM, Doyle GV, Matera J, Allard WJ, Miller MC, Fritsche HA, Hortobagyi GN, Terstappen LW: Circulating tumor cells: a novel prognostic factor for newly diagnosed metastatic breast cancer. J Clin Oncol 2005;23:1420-30.

9 Ellis MJ, Miller MC, Cristofanilli M, Budd GT, Stopeck A, Hayes DF, Doyle GV, Matera J, Terstappen LW: Prognostic and predictive value of circulating tumor cells in metastatic breast cancer patients treated with endocrine or chemotherapy. Breast Cancer Res Treat 2005;94(suppl 1):abstr 6.

10 Frazier TG, Flynn MS, Sieling BA, Herman M, Rao CS, Gross S, Miller MC, Doyle GV, Terstappen LW: Peri-operative assessment of circulating tumor cells in blood, disseminated tumor cells in bone marrow, and tissue gene signatures in patients with primary breast cancer. Breast Cancer Res Treat 2005;94 (suppl 1):abstr 1016.

11 Almokadem S, Leitzel K, Harvey HA, Bannon E, Ali SM, Miller MC, Repollet M, Terstappen LW, Doyle GV, Frazier T, Lipton A: Circulating tumor cells in adjuvant breast cancer patients. Breast Cancer Res Treat 2005;94(suppl 1):abstr 2006.
12 Smirnov DA, Zweitzig DR, Foulk BW, Miller MC, Doyle GV, Pienta KJ, Meropol NJ, Weiner LM, Cohen SJ, Moreno JG, Connelly MC, Terstappen LW, O'Hara SM: Global gene expression profiling of circulating tumor cells. Cancer Res 2005;65: 4993-7.

13 Aft RL, Ylagan L, Fleming T, Weilbaecher K, Naughton M, Watson M: Isolation and gene expression profiling of bone marrow disseminated tumor cells from women with locally advanced breast cancer. Breast Cancer Res Treat 2005;94 (suppl 1):abstr 1022.

14 Zippelius A, Kufer P, Honold G, Kollermann MW, Oberneder R, Schlimok G, Riethmuller G, Pantel $\mathrm{K}$ : Limitations of reverse-transcriptase polymerase chain reaction analyses for detection of micrometastatic epithelial cancer cells in bone marrow. J Clin Oncol 1997;15:2701-8.

15 Silva AL, Diamond J, Silva MR, Passos-Coelho JL: Cytokeratin 20 is not a reliable molecular marker for occult breast cancer cell detection in hematological tissues. Breast Cancer Res Treat 2001;66: 59-66.

16 Harris LN, Solomon N, Roberts L, Ngo T, Abi Raad R, Gioioso C, Kuter I, Smith B, Iglehart JD, Friedman P, Taghian A: Detection and monitoring of circulating tumor cells (CTCs) by CK-19 mRNA in breast cancer patients treated with neoadjuvant chemotherapy: a marker of early recurrence. Breast Cancer Res Treat 2005;94(suppl 1):abstr 1021.

17 Kataoka A, Masuda T, Ohno S, Inoue H, Yamaguchi H, Uchida Y, Mimori K, Mori M: Detection of circulating tumor cells in peripheral blood and bone marrow by quantitative RT-PCR assay for cytokeratin-7 mRNA in breast cancer patients. Breast Cancer Res Treat 2005;95(suppl 1):abstr 1020.

18 Chambers AF, Groom AC, MacDonald IC: Dissemination and growth of cancer cells in metastatic sites. Nat Rev Cancer 2002;2:563-72.

19 Fidler IJ: The pathogenesis of cancer metastasis: the 'seed and soil' hypothesis revisited. Nat Rev Cancer 2003;3:453-8.

20 Yokota J: Tumor progression and metastasis. Carcinogenesis 2000;21:497-503.

21 Bernards R, Weinberg RA: A progression puzzle. Nature 2002;418:823.
22 Van't Veer LJ, Dai H, van de Vijver MJ, He YD, Hart AA, Mao M, Peterse HL, van der Kooy K, Marton MJ, Witteveen AT, Schreiber GJ, Kerkhoven RM, Roberts C, Linsley PS, Bernards R, Friend SH: Gene expression profiling predicts clinical outcome of breast cancer. Nature 2002;415: 530-6.

23 Van de Vijver MJ, He YD, van't Veer LJ, Dai H, Hart AA, Voskuil DW, Schreiber GJ, Peterse JL, Roberts C, Marton MJ, Parrish M, Atsma D, Witteveen A, Glas A, Delahaye L, van der Velde T, Bartelink H, Rodenhuis S, Rutgers ET, Friend SH, Bernards R: A gene-expression signature as a predictor of survival in breast cancer. N Engl J Med 2002;347:1999-2009.

24 Massague J: Breast cancer metastasis genes and functions. Breast Cancer Res Treat 2005;94(suppl 1):Minisymposium 2.

25 Minn AJ, Gupta GP, Siegel PM, Bos PD, Shu W, Giri DD, Viale A, Olshen AB, Gerald WL, Massague J: Genes that mediate breast cancer metastasis to lung. Nature 2005;436:518-24.

26 Minn AJ, Kang Y, Serganova I, Gupta GP, Giri DD, Doubrovin M, Ponomarev V, Gerald WL, Blasberg R, Massague J: Distinct organ-specific metastatic potential of individual breast cancer cells and primary tumors. J Clin Invest 2005;115: 44-55.

27 Davidson B, Konstantinovsky S, Nielsen S, Dong HP, Berner A, Vyberg M, Reich R: Altered expression of metastasis-associated and regulatory molecules in effusions from breast cancer patients: a novel model for tumor progression. Clin Cancer Res 2004;10:7335-46.

28 Moulder SL, Enkemann S, Dupont E, Riker A, Furman B, Carter WB, Hoover S, Cox C, Eschrich SA, Yeatman T, Diaz NH: The use of DNA microarray to determine potential pathways of tumor cell metastasis. Breast Cancer Res Treat 2005;94 (suppl 1):abstr 4069

29 Cabioglu N, Sahin AA, Guray M, Islam R, Morandi P, Meric-Bernstam F, Hortobagyi GN, Cristofanilli M: Increased expression of CD44 in visceral metastases of breast cancer. Breast Cancer Res Treat 2005;94(suppl 1):abstr 4073. 